\title{
Contribution to the chromosome numbers of some vascular plants from Israel and Russia
}

\section{Новые данные по числам хромосом некоторых сосудистых растений из Израиля и России}

\author{
M.N. Lomonosova ${ }^{1}$, A.P. Sukhorukov ${ }^{2}$ \\ М.Н. Ломоносова ${ }^{1}$, А.П. Сухоруков ${ }^{2}$ \\ ${ }^{1}$ Central Siberian Botanical Garden, Russian Academy of Science, Zolotodolinskya Street 101, 630090, Novosibirsk, Russia. \\ ${ }^{1}$ Центральный сибирский ботанический сад Российской акаделии наук, ул. Золотодолинская, 101, 630090 Новосибирск, \\ Pоссия. E-mail: mlomonosova@mail.ru
}

${ }^{2}$ M.V. Lomonosov Moscow State University, Leninskie Gory 1/12; 119991, Moscow, Russia ${ }^{2}$ Московский государственный университет им. М.В. Ломоносова, Ленинские горы, 1/12, Москва, Россия. E-mail:suchor@mail.ru

Key words: chromosome numbers, Amaranthaceae, Asteraceae, Caryophyllaceae, Chenopodiaceae, Frankeniaceae, Israel, Russia.

Ключевые слова: числа хромосом, Amaranthaceae, Asteraceae, Caryophyllaceae, Chenopodiaceae, Frankeniaceae, Израиль, Россия.

Summary. Somatic chromosome numbers of 10 species of Amaranthaceae s. str., Asteraceae, Caryophyllaceae, Chenopodiaceae and Frankeniaceae were counted. Chromosome numbers of Atriplex intracontinentalis Sukhor. $(2 n=18)$, Corispermum filifolium C. A. Mey. ex Becker $(2 n=18)$ and Frankenia tuvinica Lomon. ( $2 n$ $=20$ ) have not been reported before. With the exception of Gypsophila capillaris (Forssk.) C. Chr., chromosome numbers of Amaranthus albus L. $(2 n=32)$, Dyssodia tenuiloba (DC) B.L. Rob. $(2 n=24)$, Lactuca viminea (L.) J. Presl et C. Presl $(2 n=18)$, Tragopogon coelesyriacus Boiss. $(2 n=12)$, Chenopodium opulifolium Schrad. ex W.D.J. Koch \& Ziz $(2 n=54)$, Chenopodium missouriense Aellen $(2 n=54)$ have not previously been counted using material growing in Israel.

Аннотация. Приведены числа хромосом для 10 видов из семейств Amaranthaceae s. str., Asteraceae, Caryophyllaceae, Chenopodiaceae и Frankeniaceae. Для Atriplex intracontinentalis Sukhor. $(2 n=18)$, Corispermum filifolium C. A. Mey. ex Becker $(2 n=18)$ и Frankenia tuvinica Lomon. $(2 n=20)$ числа хромосом не были известны ранее. Впервые на материале из Израиля указаны числа хромосом для Amaranthus albus
L. $(2 n=32)$, Dyssodia tenuiloba (DC) B.L. Rob. $(2 n=$ 24), Lactuca viminea (L.) J. Presl et C. Presl $(2 n=18)$, Tragopogon coelesyriacus Boiss. $(2 n=12)$, Chenopodium opulifolium Schrad. ex W.D.J. Koch et Ziz $(2 n=54)$ и Chenopodium missouriense Aellen $(2 n=54)$.

For chromosome counts, the seeds were germinated in petri dishes. The root tips were pretreated in $0.1 \%$ colchicine for two hours, fixed in ethanol-acetic acid (3:1) and subsequently stained with $1 \%$ acetic hematoxylin (Smirnov, 1968). The observations of chromosomes of the mitotic metaphases were made using an Axioscop-40 light microscope with built-in AxioCam MRc 5 video camera (Carl Zeiss, Germany). Chromosome numbers in the literature were checked using Index to Plant Chromosome Numbers (Goldblatt et Johnson, 1979+) and Chromosome Counts Database (Rice et al., 2015). Three or fewer chromosome counts for the species are discussed in detail.

A single asterisk (*) indicates the first chromosome count for the species; a double asterisk 
$(* *)$ indicates the first chromosome count from the species collected in Israel.

\section{Amaranthaceae}

**Amaranthus albus L. $-\mathbf{2 n}=\mathbf{3 2}$.

"Israel, Golan Heights, near Merom village, roadside, 6 X 2012, A. Shmida, A. Sukhorukov, M. Kushunina s. n." (MW).

The same chromosome number for this species has been reported by many authors (Rice et al., 2015).

\section{Asteraceae}

**Dyssodia tenuiloba (DC) B.L. Rob. $-\mathbf{2 n}=\mathbf{2 4}$.

"Israel, Dead Sea, Ein Bokek, weed near hotels, 9 X 2012, A. Sukhorukov, M. Kushunina, 294" (MW).

The same chromosome compliment is known from Pakistan (Razaq et al., 1994) and USA (Strother, 1989 sub Thymophylla tenuiloba (DC) Small).

**Lactuca viminea (L.) J. Presl et C. Presl $-\mathbf{2 n}$ $=18$.

"Israel, Golan Heights, semi-desert, 6 X 2012, A. Sukhorukov, M. Kushunina, A. Shmida s. n." (MW).

The literature data have always pointed to diploid number $2 n=18$ (Rice et al., 2015)

**Tragopogon coelesyriacus Boiss. $-\mathbf{2 n}=\mathbf{1 2}$.

"Israel, Jerusalem, Giv'at Ram, near university campus, weed, 1 V 2012, A. Sukhorukov s. n." (MW).

This chromosome number confirms the earlier counts reported by Wilson (1983) based on material from Iraq, Jordan, Lebanon and Turkey.

\section{Caryophyllaceae}

Gypsophila capillaris (Forssk.) C. Chr. $-\mathbf{2 n}=$ 36.

"Israel, West bank, 20 km E from Jerusalem, hill slope, 8 X 2012, A. Sukhorukov, M. Kushunina, A. Shmida s. n." (MW).
The same number is known from previous investigation (Waisel, 1962 sub G. rokejeka Delile).

\section{Chenopodiaceae}

* Atriplex intracontinentalis Sukhor. $-\mathbf{2 n}=\mathbf{1 8}$.

"Russia, Samara prov., near Sancheleevo village, saline meadow with Camphorosma songorica and Puccinellia sp. 22 IX 2013, M. Lomonosova 1063a" (NS).

**Chenopodium opulifolium Schrad. ex W.D.J. Koch et $\mathrm{Ziz}-\mathbf{2 n}=\mathbf{5 4}$.

"Israel, Jerusalem, Giv'at Ram, weed near the university campus, 5 X 2012, A. Sukhorukov, M. Kushunina s. n." (MW).

Only hexaploidy is reported in the literature (for more see Mandák et al. (2012).

$* *$ Chenopodium missouriense Aellen $-\mathbf{2 n}=\mathbf{5 4}$.

"Israel. Jerusalem, Giv’at Ram, weed, 5 X 2012, A. Sukhorukov s. n." (W, NS).

The same chromosome compliment for this taxon was established for Sweden (Kjellmark, 1934), USA (Keener, 1970) and Canada (Bassett, Crompton, 1982 sub C. album var missouriense (Aellen) Bassett et Crompton).

*Corispermum filifolium C. A. Mey. ex Becker $\mathbf{2 n}=\mathbf{1 8}$.

"Russia, Volgograd prov., beside the Volga river in Volgograd, alluvium, 29 IX 2012, A. Sukhorukov s. n." (G).

\section{Frankeniaceae}

* Frankenia tuvinica Lomon. $-\mathbf{2 n}=\mathbf{2 0}$.

"Russia, Tyva republic, Cheder lake, solonchak with Salicornia perennans, 31 IX 2013, M. Lomonosova 979" (NS).

\section{Acknowledgements}

The work was partially supported by the Russian Foundation for Basic Research (project 15-2902664: chromosome investigations) and Russian Scientific Foundation (project 14-50-00029: identification of some plant species in diverse herbaria).

\section{LITERATURE}

Bassett I.J., Crompton C.W. The genus Chenopodium in Canada // Canad. J. Bot., 1982. - Vol. 60, No 5. - P. 586-610.

Goldblatt P., Johnson D.E. (eds.). Index to plant chromosome numbers (IPCN). [http://www.tropicos.org/Project/ IPCN (accessed 31 May 2015)].

Keener C.S. Documented plant chromosome numbers 70 : 1 // SIDA, 1970. - Vol. 3, No 7. - P. 533-536.

Kjellmark S. Einige neue Chromosomenzahlen in der Familie Chenopodiaceae // Bot. Not., 1934. - Vol. 1-2. - P. 136-140.

Mandák B., Trávníček P., Paštová L., Rořínková D. Is hybridization involved in the evolution of the Chenopodium album aggregate? An analysis based on chromosome counts and genome size estimation // Flora, 2012. - Vol. 207. - P. $530-540$ 
Razaq Z., Vahidy A.A., Ali S.I. Chromosome numbers in Compositae from Pakistan // Ann. Miss. Bot. Gard., 1994. - Vol. 81. - P. 800-808.

Rice A., Glick L., Abadi S., Einhorn M., Kopelman N.M., Salman-Minkov A., Mayzel J., Chay O., Mayrose I. The Chromosome Counts Database (CCDB) - a community resource of plant chromosome numbers // New Phytologist, 2015. - Vol. 206. - P. 19-26. [http://ccdb.tau.ac.il/ (accessed 31 May 2015)]

Smirnov Yu.A. Accelerated method for studying somatic chromosomes in fruit trees // Tsitologia, 1968. - Vol. 10, No. 12. - P. 1132-1134 [in Russian]. (Смирнов Ю.А. Ускоренный метод исследования соматических хромосом плодовых. // Цитология, 1968. - Т. 10, № 12. - С. 1132-1134).

Strother J.L. Chromosome numbers in Thymophylla (Compositae: Tageteae) // SIDA, 1989. - Vol. 13, No 3. - P. 351-358.

Waisel $\mathbf{Y}$. Ecotypic differentiation in the flora of Israel. II. Chromosome counts in some ecotype pairs // Bull. Res. Counc. Israel. Sect. 2. Bot., 1962. - Vol. 11, No 3. - P. 174-176.

Wilson F.D. Karyotypes of Tragopogon (Compositae: Lactuceae) // Brittonia, 1983. - Vol. 35. - P. 341-350. 